\title{
Heterogeneous Fenton-like oxidation of p-hydroxybenzoic acid using
} $\mathrm{Fe} / \mathrm{CeO}_{2}-\mathrm{TiO}_{2}$ catalyst

\author{
Tijani Hammedi ${ }^{1, *}$, Mohamed Triki ${ }^{2, *}$, Mayra G. Alvarez ${ }^{3}$, Jordi Llorca ${ }^{4}$, Abdelhamid \\ Ghorbel $^{1}$, Zouhaier Ksibi ${ }^{1}$ and Francesc Medina ${ }^{3}$ \\ ${ }^{1}$ Université Tunis El Manar, Faculté des Sciences de Tunis, Laboratoire de Chimie des Matériaux et \\ Catalyse, 2092 Tunis, Tunisia \\ ${ }^{2}$ Centre National des Recherches en Sciences des Matériaux, Laboratoire de Valorisation des \\ Matériaux Utiles (LVMU), Pôle Technologique Borj Cedria, 8027 Soliman, Tunisia \\ ${ }^{3}$ Departament d'Enginyeria Química, Universitat Rovira i Virgili, Av/Països Catalans 26, 43007 \\ Tarragona, Spain \\ ${ }^{4}$ Institute of Energy Technologies, Department of Chemical Engineering and Barcelona Research \\ Center in Multiscale Science and Engineering, Universitat Politècnica de Catalunya, EEBE, Eduard \\ Maristany 16, 08019 Barcelona, Spain \\ *Corresponding authors: E-mails: tijanihamm@yahoo.fr ; mhtriki@gmail.com

\section{Word count: 5435}

\section{ABSTRACT}

This paper is built on the Fenton-like oxidation of p-hydroxybenzoic acid ( $\mathrm{p}-\mathrm{HBZ}$ ) in the presence of $\mathrm{H}_{2} \mathrm{O}_{2}$ and $3 \% \mathrm{Fe}$ supported on $\mathrm{CeO}_{2}-\mathrm{TiO}_{2}$ aerogels under mild conditions. These catalysts were deeply characterized by XRD, $\mathrm{H}_{2}$-TPR, TEM, STEM and XPS. The effect of thermal treatment, $\mathrm{pH}(2-3,5,7), \mathrm{H}_{2} \mathrm{O}_{2} / \mathrm{p}-\mathrm{HBZ}$ molar ratio $(5,15,20,25)$ and reaction temperature $\left(25^{\circ} \mathrm{C}, 40{ }^{\circ} \mathrm{C}\right.$ and $\left.60{ }^{\circ} \mathrm{C}\right)$ on the catalytic properties of supported Fe catalysts are studied. Our results highlight the role of $\mathrm{CeO}_{2}$ and the calcination of the catalyst to obtain the highest catalytic properties after $10 \mathrm{~min}$ : $73 \%$ of p-HBZ conversion and $52 \%$ of TOC abatement.

Key words Fenton-like oxidation, p-hydroxybenzoic acid, Fe catalyst, $\mathrm{CeO}_{2}$ 


\section{INTRODUCTION}

Advanced oxidation processes (AOPs) have been successfully used for the treatment of wastewaters to reduce the concentration of toxic organic pollutants. This technology is based on the in situ generation of hydroxyl radicals ( $\left.\mathrm{HO}^{*}\right)$, which are highly reactive and nonselective. Wet hydrogen peroxide oxidation is one of the AOPs technologies, which is known to be efficient for the degradation of organic pollutants using hydrogen peroxide as the liquid oxidant (Hu \& Long 2016; Kurian \& Nair 2015). Since this process requires severe operation conditions and costing investment, many efforts have been made to use it at milder conditions by an appropriate catalyst (Rokhina \& Virkutyte 2011). In this context, heterogeneous Fenton-like reaction based on nanomaterials at mild conditions has gained attention as one of the most important catalytic processes for the oxidation of dissolved organic pollutants (Bokare \& Choi 2014; Hartmann et al. 2010; Munoz et al. 2015; Pouran et al. 2014). Recently, several heterogeneous catalysts have been studied in Fenton like oxidation of different organic contaminants such as Magnetite/Fe-Al-montmorillonite (Wei et al. 2017), CuFe-carbon (Wang et al. 2015), Iron-alumina (Di Luca et al. 2015), Ag/CeO (Aneggi et al. 2017) and $\mathrm{CeO}_{2}-\mathrm{H}_{2} \mathrm{O}_{2}$ system with $\mathrm{Fe}^{3+}$ doping (Cai et al. 2010). Moreover, $\mathrm{CeO}_{2}$ is able to activate $\mathrm{H}_{2} \mathrm{O}_{2}$ by a Fenton-like reaction due to the availability of $\mathrm{Ce}^{3+}$ oxygen vacancies on the oxide surface (Mamontov et al. 2000). In addition to that, the oxidation-reduction process of the Ce species occurs more easily on the surface of the particle $\left(\mathrm{Ce}^{4+} / \mathrm{Ce}^{3+}\right.$, cycle $)$, producing an easy formation and elimination of oxygen defects during catalytic applications (Campbell \& Peden 2005). The use of $\mathrm{CeO}_{2}$ as heterogeneous Fenton-like catalyst by generating $\mathrm{HO}^{\bullet}$ radicals was proved in the presence of $\mathrm{H}_{2} \mathrm{O}_{2}$ (Heckert et al. 2008) as shown by the following reactions:

$\mathrm{Ce}^{3+}+\mathrm{H}_{2} \mathrm{O}_{2}+\mathrm{H}^{+} \rightarrow \mathrm{Ce}^{4+}+\mathrm{HO}^{\bullet}+\mathrm{H}_{2} \mathrm{O}$

$\mathrm{HO}^{\bullet}+\mathrm{H}_{2} \mathrm{O}_{2} \quad \rightarrow \quad \mathrm{HO}_{2}{ }^{\bullet}+\mathrm{H}_{2} \mathrm{O}$ 
$1 \mathrm{Ce}^{4+}+\mathrm{HO}_{2}^{\cdot} \quad \rightarrow \quad \mathrm{Ce}^{3+}+\mathrm{O}_{2}+\mathrm{H}^{+}$

2 As mentioned in previous studies, the $\mathrm{HO}^{\circ}$ production depends critically on the oxide surface properties (Ji et al. 2010). Without surface modification, the reaction between $\mathrm{Ce}^{3+}$ and $\mathrm{H}_{2} \mathrm{O}_{2}$ leads to the formation of stable brown peroxide-like species $\left(\mathrm{Ce}^{3+}-\mathrm{OOH}^{-}\right)$, which remain

stable even at neutral $\mathrm{pH}$ and do not directly decompose to generate free $\mathrm{HO}^{\bullet}$ (Chen et al. 2012). The peroxide species are relatively chemically stable in the absence of organic contaminants and can only degrade substances absorbed on the surface of $\mathrm{CeO}_{2}$ via an intermolecular rearrangement. As shown in schema (1), the degradation of organics is a localized surface reaction rather than a radical-attack Fenton reaction in the $\mathrm{CeO}_{2} / \mathrm{H}_{2} \mathrm{O}_{2}$ system (Wang et al. 2014).

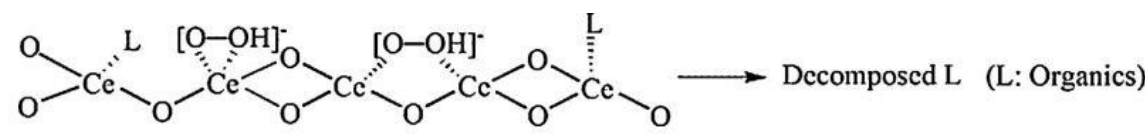

Schema (1)

Thus, the heterogeneous redox system $\mathrm{CeO}_{2}-\mathrm{H}_{2} \mathrm{O}_{2}$ can be easily manipulated by simple surface modification to efficiently generate $\mathrm{HO}^{\bullet}$ under mild acidic condition. The use of $\mathrm{CeO}_{2}$ further amplifies the effective surface concentration of $\mathrm{Ce}^{3+}$ and increases the overall $\mathrm{HO}$ • yield, due to the critical role of surface $\mathrm{Ce}^{3+}$ species on the catalytic efficiency. In our previous work, we found that $\mathrm{CeO}_{2}$, when associated with $\mathrm{TiO}_{2}$, promotes oxygen storage and enhances oxygen mobility, producing surface and bulk vacancies that improve the redox properties of the catalytic system (Hammedi et al. 2015a). However, the $\mathrm{CeO}_{2}-\mathrm{TiO}_{2}$ mixed oxides have not been investigated yet as supports for catalysts in Fenton-like oxidation.

In this work, we explored the efficiency of the $3 \% \mathrm{Fe} / \mathrm{CeO}_{2}-\mathrm{TiO}_{2}$ catalysts for the Fenton-like oxidation of p-hydroxybenzoic acid ( $\mathrm{p}-\mathrm{HBZ}$ ) in the presence of $\mathrm{H}_{2} \mathrm{O}_{2}$ at mild conditions. This molecule was chosen as a non-biodegradable model of phenolic pollutants typically found in olive oil mill wastewaters. We thoroughly studied the effect of $\mathrm{pH}, \mathrm{H}_{2} \mathrm{O}_{2}$ concentration and 
reaction temperature on the catalytic properties of supported $\mathrm{Fe}$ catalysts. The $\mathrm{CeO}_{2}-\mathrm{TiO}_{2}$ mixed oxides as well as the Fe catalysts were deeply characterized by XRD, $\mathrm{H}_{2}$-TPR, TEM, STEM and XPS.

\section{EXPERIMENTAL}

\section{Catalysts preparation}

CeTi and $\mathrm{TiO}_{2}$ were prepared via the sol-gel method as described previously (Hammedi et al. 2015a). CeTi was prepared by dissolving Cerium(III) nitrate hexahydrate in anhydrous ethanol in the presence of ethyl acetoacetate. Titanium(IV) isopropoxide was then added to the mixture in different molar ratios of Ce/Ti: 1/4, 1/5 and 1/6. Homogeneous gels, obtained after addition of $\mathrm{HNO}_{3}(0.1 \mathrm{~mol} / \mathrm{L})$, were transferred to an autoclave for a supercritical drying at $\mathrm{T}=243{ }^{\circ} \mathrm{C}$ and $\mathrm{P}=64$ bars. All samples were calcined under oxygen at $500{ }^{\circ} \mathrm{C}$ for $3 \mathrm{~h}$. $\mathrm{TiO}_{2}$ was prepared by the same described protocol without the addition of the cerium salt. The Fe (3 wt $\%$ ) catalysts were prepared by incipient wetness impregnation of the support with an aqueous solution of $\mathrm{Fe}\left(\mathrm{NO}_{3}\right)_{3} \cdot 9 \mathrm{H}_{2} \mathrm{O}$. The obtained solids were dried overnight at $90{ }^{\circ} \mathrm{C}$ for 24 $\mathrm{h}$ and then calcined under $\mathrm{O}_{2}$ at $300{ }^{\circ} \mathrm{C}$ for $2 \mathrm{~h}$. The samples were named as $3 \mathrm{Fe} / \mathrm{Ti}-\mathrm{C}$ and 3Fe/CeTi-C. Some samples were reduced under $\mathrm{H}_{2}$ for $2 \mathrm{~h}$ at $300{ }^{\circ} \mathrm{C}$ and labelled as 3Fe/CeTi-R.

\section{Catalysts characterization}

$\mathrm{N}_{2}$ physisorption studies were carried out in automatic Micromeritics ASAP 2020 apparatus. The specific surface area was determined using the Brunauer-Emmett-Teller (BET) method and the average pore size was calculated with the Barrett-Joyner-Halenda (BJH) method using isothermal desorption data. X-ray diffraction (XRD) measurements were performed using a Philips PW1050 diffractometer. The average crystallite size of the samples was estimated using the Debye-Scherrer equation. Hydrogen temperature programmed reduction $\left(\mathrm{H}_{2}-\mathrm{TPR}\right)$ profiles were obtained on a Micromeritics Autochem 2920 analyzer TPD/R/O using a thermal 
conductivity detector. The catalyst was treated under $\mathrm{O}_{2}(5 \%) / \mathrm{He}$ at $300{ }^{\circ} \mathrm{C}$ for $1 \mathrm{~h}$ and then reduced from $40{ }^{\circ} \mathrm{C}$ to $700{ }^{\circ} \mathrm{C}$ with $\mathrm{H}_{2}(5 \%) / \mathrm{Ar}(30 \mathrm{~mL} / \mathrm{min})$. Transmission electron microscopy (TEM) images were acquired using a JEOL JEM-1011 microscope operating at $80 \mathrm{kV}$. High-angle annular dark-field scanning transmission electron microscopy (STEM) and energy dispersive X-ray analysis (EDX) were carried out at $200 \mathrm{kV}$ with a Tecnai G2 F20 STWIN instrument equipped with a field emission electron source. X-ray photoelectron spectroscopy (XPS) was performed on a SPECS system equipped with an Al anode XR50 source operating at $150 \mathrm{~mW}$ and a Phoibos MCD-9 detector. The pass energy of the hemispherical analyzer was set at $25 \mathrm{eV}$ and the energy step was set at $0.1 \mathrm{eV}$. The pressure in the analysis chamber was kept below $10^{-7} \mathrm{~Pa}$.

\section{Catalytic oxidation experiments}

Catalytic tests were performed in a glass reactor at atmospheric pressure using $100 \mathrm{~mL}$ of $\mathrm{p}-$ HBZ aqueous solution (10 mmol/L) over supported Fe catalyst $(30 \mathrm{mg})$ at fixed $\mathrm{pH}$ and temperature between $25^{\circ} \mathrm{C}$ and $60{ }^{\circ} \mathrm{C}$. The desired $\mathrm{pH}(2,3.2,5$ and 7$)$ of the solution was adjusted using $\mathrm{HCl}(0.1 \mathrm{mmol} / \mathrm{L})$ or $\mathrm{NaOH}(0.1 \mathrm{mmol} / \mathrm{L})$. After stirring for $30 \mathrm{~min}$ in order to reach the $\mathrm{p}-\mathrm{HBZ}$ adsorption equilibrium, a volume of $\mathrm{H}_{2} \mathrm{O}_{2}$ was added to the solution and the reaction started. It is important to note that samples were withdrawn to assess adsorption before the addition of $\mathrm{H}_{2} \mathrm{O}_{2}$. The $\mathrm{H}_{2} \mathrm{O}_{2}$ /p- $\mathrm{HBZ}$ molar ratio of $14 / 1$ corresponds to the stoichiometric quantity needed for the total oxidation of $\mathrm{p}-\mathrm{HBZ}$ to $\mathrm{CO}_{2}$ and $\mathrm{H}_{2} \mathrm{O}$ according to the following reaction:

$\mathrm{C}_{7} \mathrm{H}_{6} \mathrm{O}_{3}+14 \mathrm{H}_{2} \mathrm{O}_{2} \quad \rightarrow \quad 7 \mathrm{CO}_{2}+17 \mathrm{H}_{2} \mathrm{O}$

Therefore, $0.123 \mathrm{~mL}$ of $\mathrm{H}_{2} \mathrm{O}_{2}(11 \mathrm{~mol} / \mathrm{L})$ was added into the reactor to get a $\mathrm{H}_{2} \mathrm{O}_{2} / \mathrm{p}-\mathrm{HBZ}$ molar ratio of 14/1. Different $\mathrm{H}_{2} \mathrm{O}_{2} / \mathrm{p}-\mathrm{HBZ}$ molar ratios $(5,15,20$ and 25) are studied. The concentrations of $\mathrm{p}-\mathrm{HBZ}$ and intermediates were monitored by high performance liquid chromatography (HPLC, Waters 1515) at $\lambda=254 \mathrm{~nm}$ using a Hypersil Gold C18 column and 
acetonitrile/ $\mathrm{H}_{2} \mathrm{O} / \mathrm{H}_{2} \mathrm{SO}_{4}(0.005 \mathrm{~mol} / \mathrm{L})(20 / 70 / 10)$ as mobile phase. Total Organic Carbon (TOC) was measured with a Shimadzu Model 5050 TOC analyzer. The initial reaction rate was calculated from the curve $\mathrm{C}$ versus time where $\mathrm{C}$ is the concentration of $\mathrm{p}-\mathrm{HBZ}$ after oxidation. It corresponds to the slope of the linear part of the curve at low p-HBZ conversion $(<10 \%$ of conversion).

\section{RESULTS AND DISCUSSION}

\section{Catalysts characterization}

Table 1 shows the textural and structural properties of the prepared materials. BET surface areas of the $\mathrm{CeO}_{2}-\mathrm{TiO}_{2}$ materials are higher than the area obtained for pure $\mathrm{TiO}_{2}$. This result could be attributed to the inhibition of particles growth for the CeTi mixed oxides, which can be verified by TEM analysis. As the content of cerium increases, the $\mathrm{S}_{\mathrm{BET}}$ of CeTi increases to $183 \mathrm{~m}^{2} / \mathrm{g}$ for a $\mathrm{Ce} / \mathrm{Ti}$ ratio of $1 / 5$. This result could be due to the modification of the hydrolysis-condensation reactions rates by the cerium nitrate (Lopez et al. 2004). However, a decrease in pore diameter is observed when adding $\mathrm{Ce}$ to $\mathrm{TiO}_{2}$, which could be due to the higher bond length of $\mathrm{Ce}-\mathrm{O}(2.343 \AA$ ) (Shoko et al. 2009) compared to the bond length of TiO (1.952 A) (Brown \& Shannon 1973). BET surface areas of the supported Fe catalysts are lower than those of bare CeTi. In fact, the $\mathrm{S}_{\mathrm{BET}}$ of $3 \mathrm{Fe} / \mathrm{CeTi}-\mathrm{C}$ and $3 \mathrm{Fe} / \mathrm{CeTi}-\mathrm{R}$ are $133 \mathrm{~m}^{2} / \mathrm{g}$ and $142 \mathrm{~m}^{2} / \mathrm{g}$, respectively compared to $183 \mathrm{~m}^{2} / \mathrm{g}$ for the CeTi(1/5) support. This result could be attributed to a certain blockage of the porous structure of the support by Fe species. 


\begin{tabular}{llll} 
Materials & $\mathbf{S}_{\mathbf{B E T}}\left(\mathbf{m}^{2} / \mathbf{g}\right)$ & Pore diameter $(\mathbf{n m})$ & $\mathbf{T i O}_{\mathbf{2}}$ crystallite size \\
\hline $\mathrm{TiO}_{2}$ & 82 & 21.0 & 49 \\
$\mathrm{CeTi}(1 / 4)$ & 110 & 19.7 & 40 \\
$\mathrm{CeTi}(1 / 5)$ & 183 & 9.0 & 9.0 \\
$\mathrm{CeTi}(1 / 6)$ & 124 & 16.7 & 10 \\
$3 \mathrm{Fe} / \mathrm{Ti}-\mathrm{C}$ & 76 & 8.8 & 83 \\
3Fe/CeTi-C & 133 & 11.4 & 40 \\
3Fe/CeTi-R & 142 & 10.7 & 24 \\
\hline
\end{tabular}

1

${ }^{\mathrm{a} B Y}$ XRD.

2 Figure 1 shows the XRD patterns of $\mathrm{TiO}_{2}, \mathrm{CeTi}, 3 \mathrm{Fe} / \mathrm{Ti}-\mathrm{C}$ and $3 \mathrm{Fe} / \mathrm{CeTi}$. For $\mathrm{TiO}_{2}$, only

3 peaks corresponding to anatase phase were detected (JCPDS 83-2243). For $\mathrm{CeO}_{2}$, peaks at $42 \theta=28.6^{\circ}, 33.1^{\circ}, 47.5^{\circ}$ and $56.3^{\circ}$ attributed to cubic structure were observed (JCPDS 5 43-1002). For the CeTi mixed oxides, peaks corresponding to $\mathrm{TiO}_{2}$ anatase become weaker 6 and broader, while peaks corresponding to $\mathrm{CeO}_{2}$ are weaker, compared to those of pure 7 oxides. Moreover, the crystallite size of $\mathrm{TiO}_{2}$ in $\mathrm{CeTi}$ decreases, which suggests that the $\mathrm{Ce}$ 8 species inhibit the growth of anatase crystallites (Table 1). The appearance of $\mathrm{CeO}_{2}$ phase 9 simultaneously with the decrease of $\mathrm{TiO}_{2}$ particle size is consistent with BET surface area 10 results. The XRD patterns of $\mathrm{Fe} / \mathrm{CeTi}$ are similar to those of $\mathrm{CeTi}$ without any crystalline 11 phase corresponding to iron oxide. It can be noticed that $\mathrm{TiO}_{2}$ crystalline phase in the $123 \mathrm{Fe} / \mathrm{CeTi}-\mathrm{R}$ catalyst is lower than in the calcined one (3Fe/CeTi-C). This result indicates that 13 the reduction of the catalyst could lead to the segregation of iron particles in the CeTi mixed 14 oxides. 

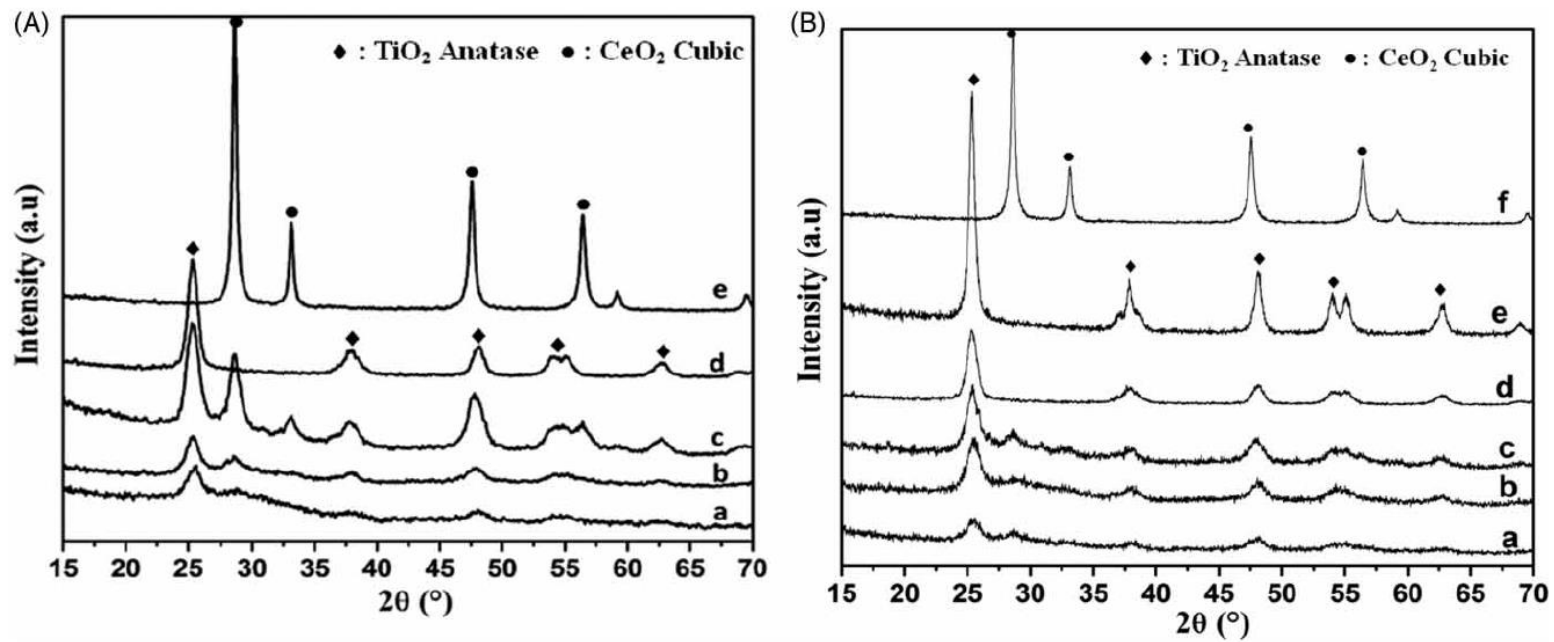

1

2 Figure 2 shows the $\mathrm{H}_{2}$-TPR profiles of the samples. Pure $\mathrm{CeO}_{2}($ Figure 2(a)) exhibits a broad 3

reduction peak at $530{ }^{\circ} \mathrm{C}$, which could be attributed to the reduction of $\mathrm{Ce}^{4+}$ to $\mathrm{Ce}^{3+}$ on the surface (Dutta et al. 2006). For the CeTi support (Figure 2(b)), the $\mathrm{H}_{2}-\mathrm{TPR}$ profile exhibits a broad reduction peak between $250{ }^{\circ} \mathrm{C}$ and $500{ }^{\circ} \mathrm{C}$ (maximum at $460{ }^{\circ} \mathrm{C}$ ), which is shifted to lower reduction temperatures compared to pure ceria. Therefore, the reduction of $\mathrm{CeO}_{2}$ in the mixed support is facilitated in comparison with pure $\mathrm{CeO}_{2}$. A broad peak for $3 \mathrm{Fe} / \mathrm{CeTi}-\mathrm{C}$ (Figure 2(c)) is observed at $330^{\circ} \mathrm{C}$, probably due to the reduction of iron oxide in strong interaction with the support (Hammedi et al. 2015b). For 3Fe/CeTi-R, a reduction peak is observed at $305{ }^{\circ} \mathrm{C}$ (Figure 2(d)), where the amount of hydrogen consumed $(607 \mu \mathrm{mol} / \mathrm{g})$ is similar to that of the calcined sample $(585 \mu \mathrm{mol} / \mathrm{g})$, which suggests that during the reduction the iron oxide species strongly interact with the CeTi support. For the $3 \mathrm{Fe} / \mathrm{Ti}-\mathrm{C}$ sample (Figure 2e), two broad reduction peaks are observed at 150 and $650{ }^{\circ} \mathrm{C}$. The first peak is due to the presence of iron with no interaction with the $\mathrm{TiO}_{2}$ support, while the second peak is probably due to the iron in the crystalline structure of the $\mathrm{TiO}_{2}$ support. 


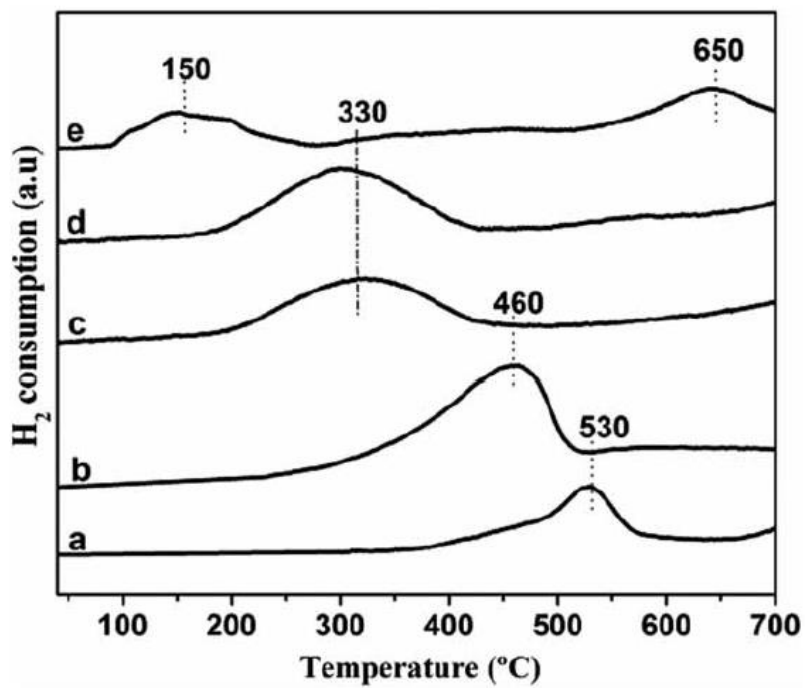

2 Figure 3 presents TEM images of $\mathrm{TiO}_{2}, \mathrm{CeTi}, 3 \mathrm{Fe} / \mathrm{CeTi}-\mathrm{R}$ and $3 \mathrm{Fe} / \mathrm{CeTi}-\mathrm{C}$. Slight

3 aggregates of $\mathrm{TiO}_{2}$ particles are observed (Figure 3(a)), although better dispersion is achieved

4 by doping with $\mathrm{CeO}_{2}$ (Figure 3(b)). This observation could explain the fact that the BET

5 surface area of $\mathrm{CeTi}$ is higher than the area obtained for pure $\mathrm{TiO}_{2}$. Since the $\mathrm{Fe}-\mathrm{Ce}$ ions are

6 inserted into the lattice of $\mathrm{TiO}_{2}$, the particles in 3Fe/CeTi-C (Figure 3(c)) and 3Fe/CeTi-R

7 (Figure 3(d)) are well dispersed. STEM images of 3Fe/CeTi-C show well-dispersed iron

8 particles at high magnification with no large aggregates (Figure S1, Supplementary

9 information). EDX analysis (Inset in Figure S1a) shows a uniform distribution of iron 10 particles of $1-2 \mathrm{~nm}$.
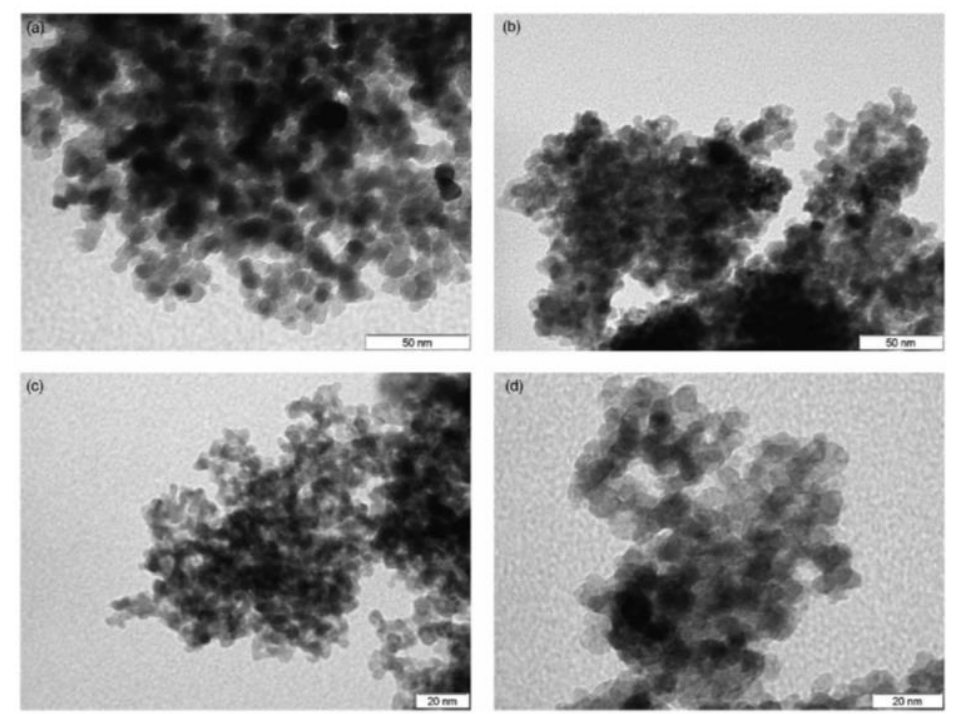
1 XPS spectra of 3Fe/CeTi-C are shown in Figure 4 and the surface atomic ratios $\mathrm{Ce} / \mathrm{Ti}, \mathrm{Fe} / \mathrm{Ti}$

2 and $\mathrm{Fe} /(\mathrm{Ce}+\mathrm{Ti}$ ) are given in Table S1 (Supplementary information). The surface atomic $\mathrm{Ce} / \mathrm{Ti}$

3 decreased in the presence of the iron species, which shows that Ce probably interacts with $\mathrm{Fe}$

4 particles. The XPS spectrum of the Fe2p region taken on the surface of 3Fe/CeTi-C (Figure

5 4(a)) shows the presence of satellite lines, indicating the presence of oxidized Fe (Nasralla $e t$

6 al. 2013). The XPS spectrum of $\mathrm{Ce} 3 \mathrm{~d}$ for 3Fe/CeTi-C (Figure 4(b)) reveals the presence of

7 both $\mathrm{Ce}(\mathrm{III})$ and $\mathrm{Ce}(\mathrm{IV})$. The $\mathrm{CeTi}$ sample contained $17.2 \%$ of reduced $\mathrm{Ce}(\mathrm{III})$, whereas

$83 \mathrm{Fe} / \mathrm{CeTi}-\mathrm{C}$ contained $22.2 \%$ of $\mathrm{Ce}(\mathrm{III})$. This means that the transition metal promotes the

9 reduction of $\mathrm{CeO}_{2}$ on the surface, suggesting a strong contact between the metal nanoparticles

(a)
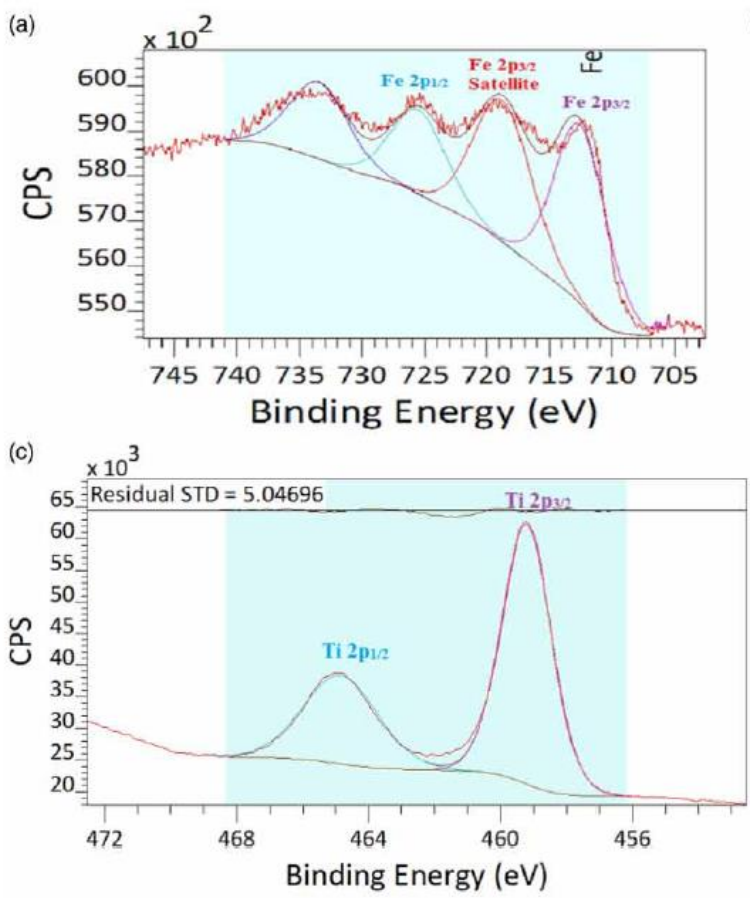

15 and the support. $\mathrm{Ce}^{3+}$ induces the formation of oxygen vacancies in the material, which are essential for adsorption/dissociation of oxygen molecules during the oxidation. The XPS spectrum of $\mathrm{Ti} 2 \mathrm{p}$ for $3 \mathrm{Fe} / \mathrm{CeTi}-\mathrm{C}$ (Figure $4(\mathrm{c})$ ) indicates the presence of $\mathrm{Ti}^{4+}$ in the $\mathrm{CeTi}$ mixed oxides. The XPS binding energy of $\mathrm{O} 1 \mathrm{~s}$ at $530.4 \mathrm{eV}$ is assigned to lattice oxygen, while the peak at $532.8 \mathrm{eV}$ is ascribed to surface hydroxyl species (Figure 4(d)).

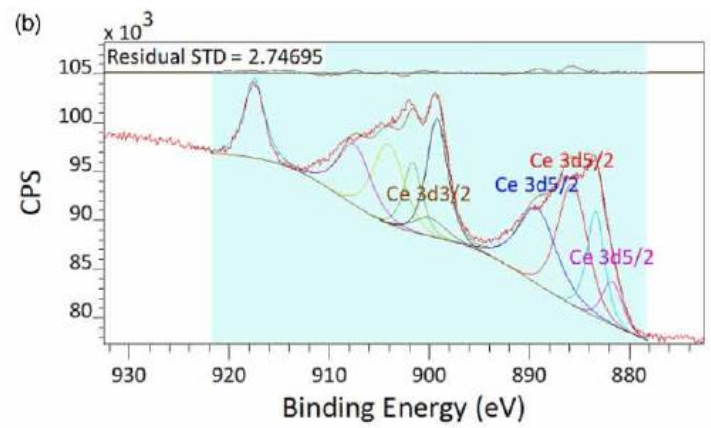

(d)

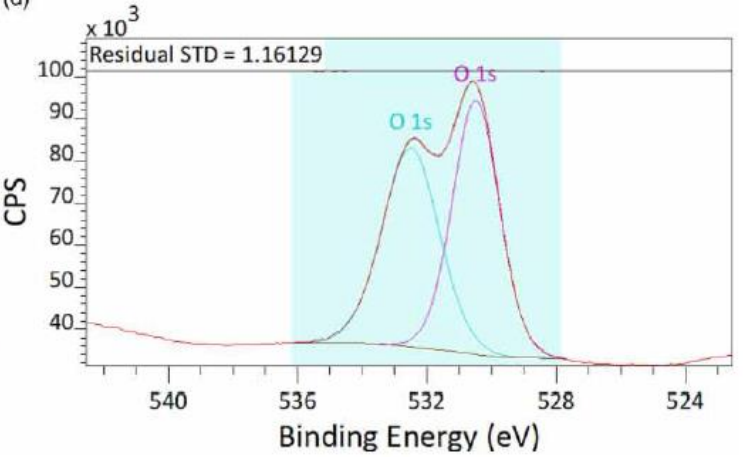




\section{Catalytic results}

Blank experiments were carried out to evaluate the eventual contribution of the non-catalytic system in $\mathrm{p}-\mathrm{HBZ}$ oxidation and $\mathrm{H}_{2} \mathrm{O}_{2}$ decomposition. The results show that, without catalyst, the oxidation of $\mathrm{p}-\mathrm{HBZ}$ and the decomposition of $\mathrm{H}_{2} \mathrm{O}_{2}$ are negligible at $60{ }^{\circ} \mathrm{C}$ using a $\left(\mathrm{H}_{2} \mathrm{O}_{2} / \mathrm{p}-\mathrm{HBZ}\right)$ molar ratio of $14 / 1$. Moreover, the results show that the adsorption of $\mathrm{p}-\mathrm{HBZ}$ on the solid remains below $5.0 \%$. In order to fix the amount of catalyst, experiments were performed in the presence of $3 \mathrm{Fe} / \mathrm{CeTi}-\mathrm{C}(15 \mathrm{mg}, 20 \mathrm{mg}$ and $30 \mathrm{mg})$ at $60{ }^{\circ} \mathrm{C}$. We chose to perform the reaction with $30 \mathrm{mg}$ of catalyst to ensure that there are no mass transfer limitations as shown in Figure S2 (Supplementary information). Table 2 regroups the initial reaction rates and the catalytic properties of supported Fe catalysts for the oxidation of $\mathrm{p}$ $\mathrm{HBZ}$ at $60{ }^{\circ} \mathrm{C}$. The results show that $3 \mathrm{Fe} / \mathrm{CeTi}-\mathrm{C}$ leads to $73 \%$ of $\mathrm{p}-\mathrm{HBZ}$ conversion after 10 min, compared to $37 \%$ with $3 \mathrm{Fe} / \mathrm{Ti}-\mathrm{C}$ and $2.5 \%$ with $3 \mathrm{Fe} / \mathrm{CeTi}-\mathrm{R}$. These results could be related to the fact that $3 \mathrm{Fe} / \mathrm{CeTi}-\mathrm{C}$ presents a high surface area, high content of oxygen vacancies and a high concentration of $\mathrm{Ce}^{3+}$, permitting enhancement of oxygen adsorption on the catalyst surface, and so increasing the catalytic activity. In addition, the initial reaction rates of the supported $\mathrm{Fe}$ catalysts are quite high. However, the calcined catalyst $(3 \mathrm{Fe} / \mathrm{CeTi}-$ C) is more active than $3 \mathrm{Fe} / \mathrm{CeTi}-\mathrm{R}$ since its initial reaction rate reaches $0.166 \mathrm{mmol} /(\mathrm{g} \cdot \mathrm{min})$ compared to $0.11 \mathrm{mmol} /(\mathrm{g} \cdot \mathrm{min})$ for the reduced catalyst. The low initial reaction rate showed by the reduced catalyst suggests an induction period needed for this catalyst (3Fe/CeTi-R). This period could be due to a reduced concentration of chemisorbed oxygen and/or weakly bonded oxygen species on the CeTi mixed oxides. Despite $3 \mathrm{Fe} / \mathrm{CeTi}-\mathrm{C}$ and $3 \mathrm{Fe} / \mathrm{CeTi}-\mathrm{R}$ show similar TPR profiles, it seems reasonable that the reduction step provokes changes at the material surface, which is mirrored on the catalytic activity. This reduction removes the surface oxygen species, so a re-oxidation step is necessary before the Fenton reaction. Hydroquinone and maleic acid are identified as intermediates and the evolution of their 
1 concentrations during the oxidation of $\mathrm{p}-\mathrm{HBZ}$ over $3 \mathrm{Fe} / \mathrm{Ti}-\mathrm{C}, 3 \mathrm{Fe} / \mathrm{CeTi}-\mathrm{C}$ and $3 \mathrm{Fe} / \mathrm{CeTi}-\mathrm{R}$

2 is shown in Figure 5. Hydroquinone is produced at higher concentration, while maleic acid is

3 produced at a lower concentration. In the presence of $3 \mathrm{Fe} / \mathrm{Ti}-\mathrm{C}$, the concentration of

4 hydroquinone reaches $0.397 \mathrm{mmol} / \mathrm{L}$ after $10 \mathrm{~min}$ and then decreases slightly after $1 \mathrm{~h}$ of

5 reaction. However, the $3 \mathrm{Fe} / \mathrm{CeTi}-\mathrm{C}$ catalyst leads to the highest hydroquinone concentration

$6(0.478 \mathrm{mmol} / \mathrm{L})$ after $10 \mathrm{~min}$, which decreases rapidly after $30 \mathrm{~min}$ of reaction.

\begin{tabular}{|c|c|c|c|c|c|}
\hline \multirow[b]{2}{*}{ Catalysts } & \multirow[b]{2}{*}{$\mathbf{R}_{0}{ }^{a}(\operatorname{mmol} /(g \cdot m i n))$} & \multirow[b]{2}{*}{ TOC abatement (\%) after $1 \mathrm{~h}$} & \multirow[b]{2}{*}{ p-HBZ conversion $(\%)$ after $10 \mathrm{~min}$} & \multicolumn{2}{|c|}{ Selectivity (\%) at $10 \mathrm{~min}$} \\
\hline & & & & Hydroquinone & Maleic acid \\
\hline $3 \mathrm{Fe} / \mathrm{Ti}-\mathrm{C}$ & 0.150 & 48 & 37 & 5.9 & 0.03 \\
\hline $3 \mathrm{Fe} / \mathrm{CeTi}-\mathrm{C}$ & 0.166 & 52 & 73 & 15.0 & 0.31 \\
\hline 3Fe/CeTi-R & 0.110 & 42 & 2.5 & 1.2 & 0.06 \\
\hline
\end{tabular}

7
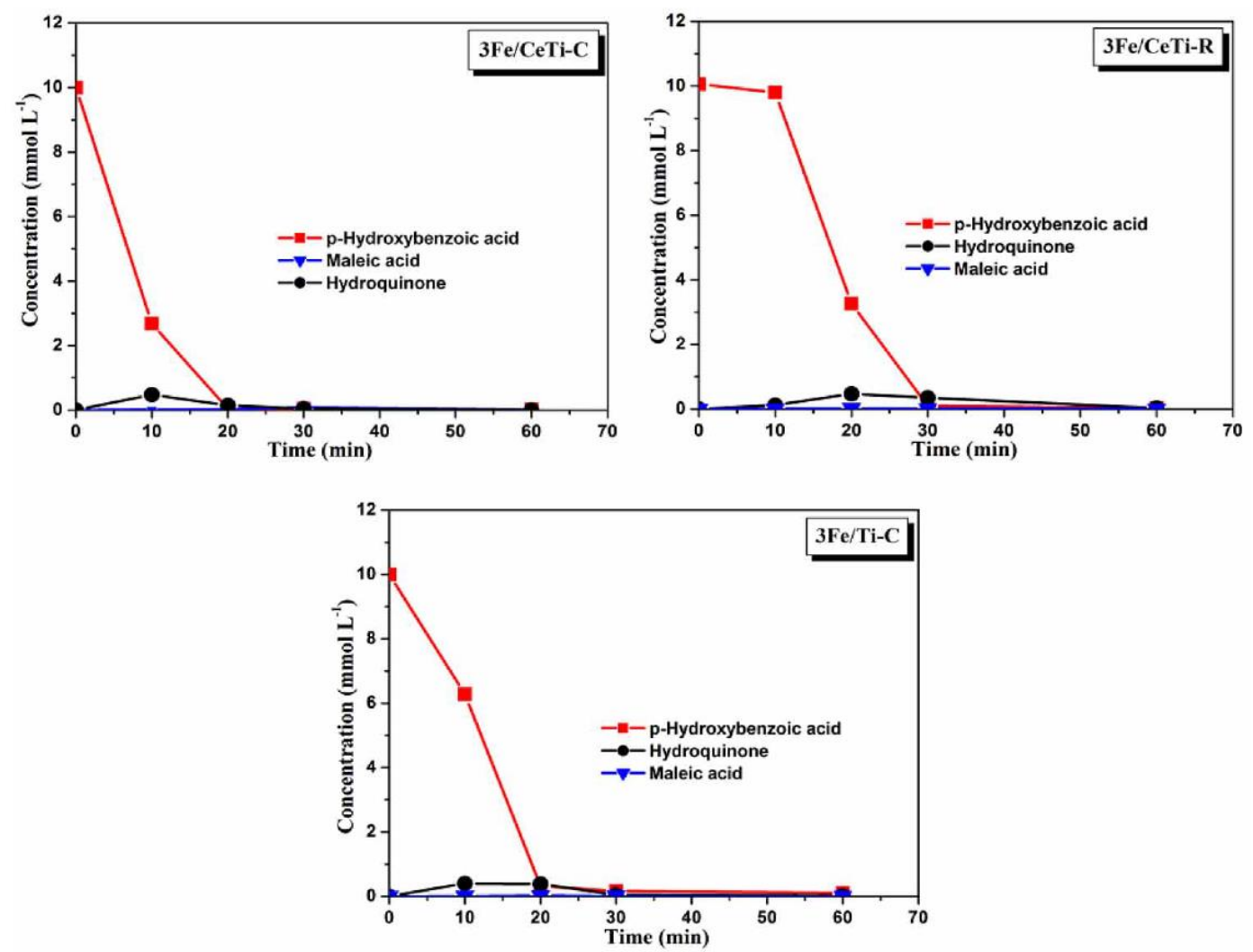

9 Effect of $\mathrm{pH}$

10 The effect of $\mathrm{pH}$ on $\mathrm{p}-\mathrm{HBZ}$ oxidation over $3 \mathrm{Fe} / \mathrm{CeTi}-\mathrm{C}$ in the presence of $\mathrm{H}_{2} \mathrm{O}_{2}$ is shown in

11 Figure 6. The results show that the catalytic properties are affected when $\mathrm{pH}$ increases. In

12 fact, $\mathrm{p}-\mathrm{HBZ}$ conversion is higher than $70 \%$ after $10 \mathrm{~min}$ at $\mathrm{pH} 2-3$, whereas it decreases to 
$112 \%$ and $1.0 \%$ at $\mathrm{pH} 5$ and $\mathrm{pH} 7$, respectively. This result could be related to a decrease of the

2 oxidation potential of ${ }^{\circ} \mathrm{OH}$ due to the increase of $\mathrm{pH}$ (Kwnon et al. 1999). Moreover, some active iron species cannot exist at neutral $\mathrm{pH}$ and thus cannot establish an effective Fentonlike reaction. When $\mathrm{pH}$ decreases, a sufficient amount of $\mathrm{H}_{2} \mathrm{O}_{2}$ is available producing hydroxyl radicals due to the generation of carboxylic acids. However, when $\mathrm{pH}$ increases, precipitation of insoluble ferric hydroxides takes place and the decomposition of $\mathrm{H}_{2} \mathrm{O}_{2}$ becomes preponderant. Therefore, at high $\mathrm{pH}$, hydrogen peroxide is decomposed into $\mathrm{H}_{2} \mathrm{O}$ and $\mathrm{O}_{2}$ due to the iron precipitate, which suppresses the ${ }^{\circ} \mathrm{OH}$ generation. Due to this decomposition, fewer hydroxyl radicals are formed and so weaker degradation efficiency is achieved (Sreeja \& Sosamony 2016). It could be concluded that $\mathrm{pH}$ value affects the formation of ${ }^{\circ} \mathrm{OH}$ radicals and so the degradation efficiency, which reaches the maximum at $\mathrm{pH} 2$, in the photo-Fenton-like processes. In our previous work (Hammedi et al. 2015b), no Fe leaching with high extent was observed and the inductive coupled plasma analyses showed that the maximum of $\mathrm{Fe}$ concentration detected in the solution was $5.4 \mathrm{mg} / \mathrm{L}$ at $\mathrm{pH} 3.4$ after 1 $\mathrm{h}$ of reaction. This represents a leaching of $6.0 \%$ of Fe in the solution, indicating reasonably good stability in acidic $\mathrm{pH}$, and probably the amount of leached $\mathrm{Fe}$ at higher $\mathrm{pH}$ could be considered negligible. A small contribution due to homogeneous Fenton might occur. However, this amount of leached $\mathrm{Fe}$ do not probably have a great effect on the $\mathrm{p}-\mathrm{HBZ}$ oxidation rate, since it was found that the catalytic activity is related to Fe concentrations of 10 times higher than those found in our solutions (Rivas et al. 2001). Moreover, it is important to take into account that Fe leaching has to be produced progressively, thus a low amount of Fe could be found at the first minutes of reaction. For this reason, a heterogeneous mechanism of $\mathrm{p}-\mathrm{HBZ}$ is most probably expected to occur. On the other hand, $\mathrm{CeO}_{2}$ seems to improve the catalytic stability by strengthening the interaction between $\mathrm{Fe}$ and the CeTi mixed oxides as found by $\mathrm{H}_{2}$-TPR, which may lead to low Fe leaching. 


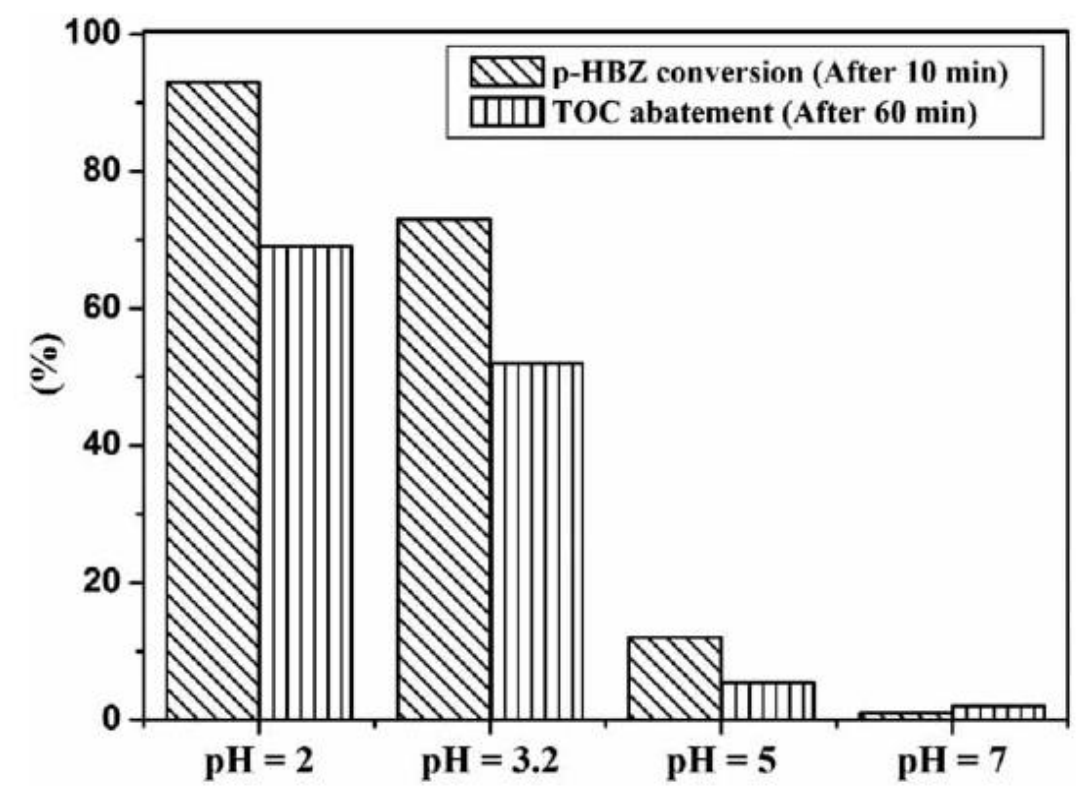

2 Effect of $\mathrm{H}_{2} \mathrm{O}_{2} / \mathrm{p}-\mathrm{HBZ}$ molar ratio

3 The Fenton-like oxidation of $\mathrm{p}-\mathrm{HBZ}$ carried out by ${ }^{\circ} \mathrm{OH}$, produced directly from the reaction

4 between $\mathrm{H}_{2} \mathrm{O}_{2}$ and $\mathrm{Fe}$ catalyst supported on CeTi. The choice of optimal $\mathrm{H}_{2} \mathrm{O}_{2} / \mathrm{p}-\mathrm{HBZ}$ molar 5 ratio, permitting the highest oxidation efficiency, is important from a practical point of view

6 due to the cost of $\mathrm{H}_{2} \mathrm{O}_{2}$. Figure 7 shows the effect of $\mathrm{H}_{2} \mathrm{O}_{2}$ concentration on $\mathrm{p}-\mathrm{HBZ}$ 7 conversion and TOC abatement when $\mathrm{p}-\mathrm{HBZ}$ oxidation was performed over $3 \mathrm{Fe} / \mathrm{CeTi}-\mathrm{C}$ at $860{ }^{\circ} \mathrm{C}$. It can be noted that the conversion of p-HBZ is enhanced with the increase of the $9 \mathrm{H}_{2} \mathrm{O}_{2} / \mathrm{p}-\mathrm{HBZ}$ molar ratio. A total conversion of $\mathrm{p}-\mathrm{HBZ}$ is achieved after $20 \mathrm{~min}$ for $\mathrm{H}_{2} \mathrm{O}_{2} / \mathrm{p}-$ HBZ molar ratios of 15 and 20 . This result could be attributed to the presence of more ${ }^{\circ} \mathrm{OH}$ radicals on the surface of $3 \mathrm{Fe} / \mathrm{CeTi}-\mathrm{C}$, which is in accordance with previous studies (Chang et al. 2018). However, when the $\mathrm{H}_{2} \mathrm{O}_{2} / \mathrm{p}-\mathrm{HBZ}$ molar ratio is 25 , the degradation efficiency is decreased to $78 \%$. Therefore, the further increase in $\mathrm{H}_{2} \mathrm{O}_{2}$ concentration does not lead to higher oxidation rate, which could probably be due to a scavenging effect of ${ }^{\circ} \mathrm{OH}$. In fact, ${ }^{\circ} \mathrm{OH}$ is a powerful scavenger, which may react with $\mathrm{H}_{2} \mathrm{O}_{2}$ according to the following reactions:

$\mathrm{H}_{2} \mathrm{O}_{2}+{ }^{\cdot} \mathrm{OH} \rightarrow \mathrm{HO}_{2}{ }^{\bullet}+\mathrm{H}_{2} \mathrm{O}$

$\mathrm{HO}_{2}{ }^{\cdot}+{ }^{\circ} \mathrm{OH} \quad \rightarrow \quad \mathrm{O}_{2}+\mathrm{H}_{2} \mathrm{O}$ 
1 The hydroperoxyl radical $\left(\mathrm{HO}_{2}{ }^{\circ}\right)$ generated is less reactive than ${ }^{\circ} \mathrm{OH}$ and does not contribute

2 to the degradation of organic pollutants, which only occurs in the presence of ${ }^{\circ} \mathrm{OH}$ radical

3 (Shukla et al. 2010; Liu et al. 2017). Therefore, an appropriate molar ratio of $\mathrm{H}_{2} \mathrm{O}_{2} / \mathrm{p}-\mathrm{HBZ}$ is

4 required to avoid the excess of $\mathrm{H}_{2} \mathrm{O}_{2}$ and so the decrease of degradation efficiency.

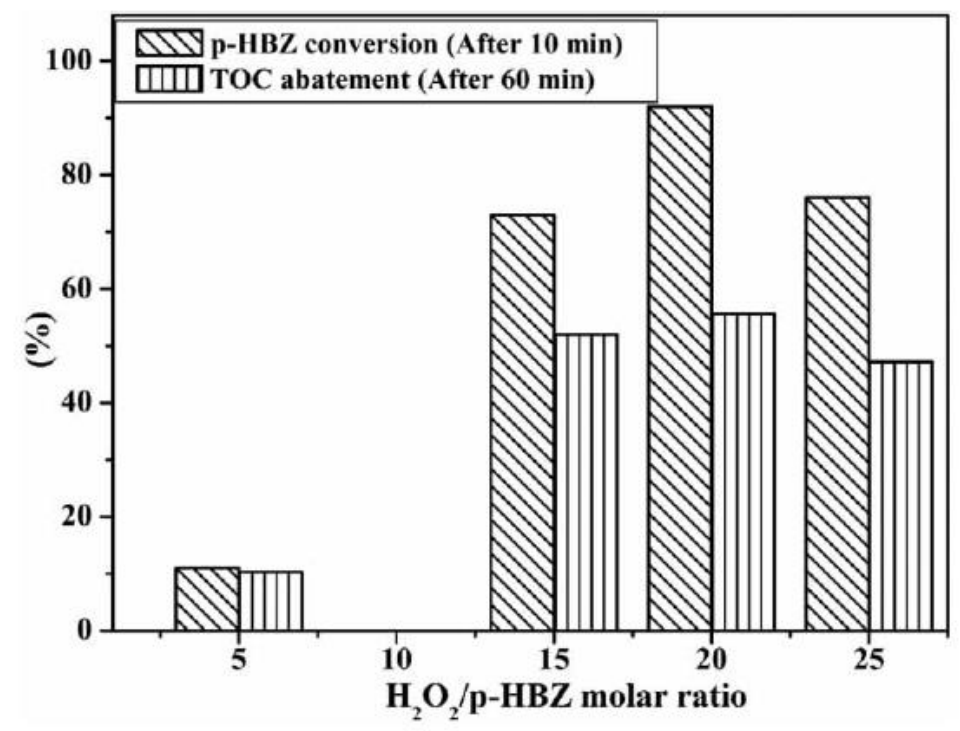

$6 \quad$ Effect of reaction temperature

7 The effect of reaction temperature on the catalytic behavior of 3Fe/CeTi-C is shown in Table

8 3. As expected, $\mathrm{p}-\mathrm{HBZ}$ conversion and TOC abatement are enhanced when the temperature 9 increases. In fact, $\mathrm{p}-\mathrm{HBZ}$ conversion increases from $7.0 \%$ to $25 \%$ at $25{ }^{\circ} \mathrm{C}$ and $40{ }^{\circ} \mathrm{C}$, 10 respectively, and reaches $73 \%$ at $60{ }^{\circ} \mathrm{C}$ after $10 \mathrm{~min}$ of reaction. Moreover, the initial reaction rates increase from $0.02 \mathrm{mmol} /(\mathrm{g} \cdot \mathrm{min})$ at $25{ }^{\circ} \mathrm{C}$ to $0.166 \mathrm{mmol} /(\mathrm{g} \cdot \mathrm{min})$ at $60{ }^{\circ} \mathrm{C}$. This result could be due to a higher rate of $\mathrm{H}_{2} \mathrm{O}_{2}$ conversion into ${ }^{\circ} \mathrm{OH}$ at higher temperature leading to a smaller amount of $\mathrm{H}_{2} \mathrm{O}_{2}$ to scavenge these radicals (Inchaurrondo et al. 2012).

\begin{tabular}{llll} 
& $\mathbf{2 5}^{\circ} \mathbf{C}$ & $\mathbf{4 0}{ }^{\circ} \mathbf{C}$ & $\mathbf{6 0}^{\circ} \mathbf{C}$ \\
\hline $\mathrm{R}_{0}^{\mathrm{a}}(\mathrm{mmol} /(\mathrm{g} \cdot \mathrm{min}))$ & 0.020 & 0.081 & 0.166 \\
p-HBZ conversion (\%) after 10 min & 7.0 & 25 & 73 \\
TOC abatement (\%) after 1 h & 37 & 48 & 52 \\
\hline
\end{tabular}

anitial reaction rate. 


\section{$1 \quad$ Kinetic study}

2 To reveal the catalytic reaction kinetics, $\ln \left(\mathrm{C}_{0} / \mathrm{C}_{\mathrm{t}}\right)$ versus time at different temperatures are

3 plotted as shown in Figure 8 . The linear fit of $\ln \left(\mathrm{C}_{0} / \mathrm{C}_{\mathrm{t}}\right)$ versus time indicates that the

4 oxidation of $\mathrm{p}-\mathrm{HBZ}$ follows a pseudo-first order kinetic. Therefore, the following equation

5 can be applied:

$6 \quad \ln \left(\mathrm{C}_{0} / \mathrm{C}_{\mathrm{t}}\right)=\left(\mathrm{k}_{\mathrm{app}}\right) \cdot \mathrm{t}$

7 where $\mathrm{C}_{0}$ and $\mathrm{C}_{\mathrm{t}}$ are the concentrations of $\mathrm{p}-\mathrm{HBZ}(\mathrm{mmol} / \mathrm{L})$ at time $0(\mathrm{~min})$ and $\mathrm{t}(\mathrm{min})$,

8 respectively, and $\mathrm{k}_{\mathrm{app}}$ is the apparent reaction rate constant $\left(\mathrm{min}^{-1}\right)$.

9 It is obvious that the apparent reaction rate constant is improved with increasing the reaction temperature. Accordingly, the apparent reaction rate constants are $0.007 \mathrm{~min}^{-1}, 0.029 \mathrm{~min}^{-1}$ and $0.125 \mathrm{~min}^{-1}$ at $25{ }^{\circ} \mathrm{C}, 40{ }^{\circ} \mathrm{C}$ and $60{ }^{\circ} \mathrm{C}$, respectively. In fact, p-HBZ oxidation is faster at high temperature due to rapid activation of $\mathrm{H}_{2} \mathrm{O}_{2}$. It is important to note that the temperature should be below $80{ }^{\circ} \mathrm{C}$ to prevent the decomposition of $\mathrm{H}_{2} \mathrm{O}_{2}$ into $\mathrm{O}_{2}$ and $\mathrm{H}_{2} \mathrm{O}$. The activation energy $\left(\mathrm{E}_{\mathrm{a}}\right)$ could be calculated according to the following Arrhenius equation:

$\ln \mathrm{k}_{\mathrm{app}}=\ln \mathrm{A}-\mathrm{E}_{\mathrm{a}} / \mathrm{RT}$

where $\mathrm{A}$ is the Arrhenius factor and $\mathrm{k}_{\mathrm{app}}$ is the apparent reaction rate constant $\left(\mathrm{min}^{-1}\right)$.

The activation energy can be calculated from the slope of the lnkapp versus $1 / \mathrm{T}$ linear curve (Figure S3, supplementary information). The $\mathrm{E}_{\mathrm{a}}$ value is determined as $67.8 \pm 0.5 \mathrm{~kJ} / \mathrm{mol}$ for the $\mathrm{p}-\mathrm{HBZ}$ oxidation over $3 \mathrm{Fe} / \mathrm{CeTi}-\mathrm{C}$.

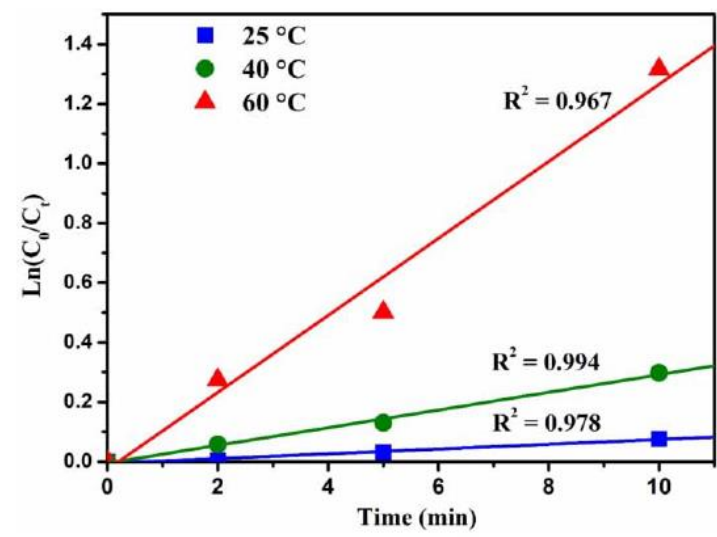




\section{CONCLUSIONS}

$3 \% \mathrm{Fe}$ supported on $\mathrm{CeO}_{2}-\mathrm{TiO}_{2}$ aerogels are prepared, characterized and evaluated in the oxidation of $\mathrm{p}-\mathrm{HBZ}$ in the presence of $\mathrm{H}_{2} \mathrm{O}_{2}$ at mild conditions. This oxidation could be considered as a Fenton-like reaction due to the production of $\mathrm{HO}^{\bullet}$ from $\mathrm{H}_{2} \mathrm{O}_{2}$ and $\mathrm{Fe}$ supported catalyst. 3Fe/CeTi-C shows the best catalytic properties, at conditions of $\mathrm{pH} 3.2$, $60{ }^{\circ} \mathrm{C}$ and $\mathrm{H}_{2} \mathrm{O}_{2} / \mathrm{p}-\mathrm{HBZ}$ molar ratio of 14 , compared to the reduced one. This catalyst reaches $0.166 \mathrm{mmol} /(\mathrm{g} \cdot \mathrm{min})$ of initial reaction rate, $73 \%$ of $\mathrm{p}-\mathrm{HBZ}$ conversion after $10 \mathrm{~min}$ and $52 \%$ of TOC abatement after $1 \mathrm{~h} . \mathrm{CeO}_{2}$ plays an important role in these good catalytic properties; this closely relies on the synergistic effect with $\mathrm{TiO}_{2}$ allowing better $\mathrm{O}_{2}$ availability to active sites due to the redox cycle of $\mathrm{Ce}^{4+} / \mathrm{Ce}^{3+}$. Further studies are required to characterize the catalyst after reaction and to check the catalyst stability in a continuous reactor. One important direction for our future work would be a greater focus on the Fenton-like oxidation of real wastewaters using supported Fe catalysts.

\section{ACKNOWLEDGMENTS}

Tunisian Ministry of Higher Education and Scientific Research and Spanish Ministry of Economy and Competitiveness are acknowledged for their financial support. F. Medina and J. Llorca would like to thank the Generalitat de Catalunya for the ICREA Academia Award.

\section{REFERENCES}

Aneggi, E., Trovarelli, A. \& Goi, D. 2017 Degradation of phenol in wastewaters via heterogeneous Fenton-like $\mathrm{Ag} / \mathrm{CeO}_{2}$ catalyst. Journal of Environmental Chemical Engineering 5, 1159-1165.

Brown, I. D. \& Shannon R. D. 1973 Empirical bond- strength-bond- length curves for oxides, Acta Crystallographica A 29, 266-282.

Bokare, A. D. \& Choi, W. 2014 Review of iron-free Fenton-like systems for activating $\mathrm{H}_{2} \mathrm{O}_{2}$ in advanced oxidation processes. Journal of Hazardous Materials 275, 121-135. 
1 Cai, W., Chen, F., Shen, X., Chen, L. \& Zhang, J. 2010 Enhanced catalytic degradation of AO7 in the $\mathrm{CeO}_{2}-\mathrm{H}_{2} \mathrm{O}_{2}$ system with $\mathrm{Fe}^{3+}$ doping. Applied Catalysis $B$ 101, 160-168.

Campbell, C. T. \& Peden, C. H. 2005 Oxygen Vacancies and Catalysis on Ceria Surfaces. Science 309, 713-714.

Chang, F., Wu, F., Zheng, J., Cheng, W., Yan, W., Deng, B. \& Hu, X. 2018 In-situ establishment of binary composites $\alpha-\mathrm{Fe}_{2} \mathrm{O}_{3} / \mathrm{Bi}_{12} \mathrm{O}_{17} \mathrm{Cl}_{2}$ with both photocatalytic and photo-Fenton features. Chemosphere 210, 257-266.

Chen, F., Shen, X., Wang, Y. \& Zhang, J. $2012 \mathrm{CeO}_{2} / \mathrm{H}_{2} \mathrm{O}_{2}$ system catalytic oxidation mechanism study via a kinetics investigation to the degradation of acid orange 7 . Applied Catalysis B 121-122, 223-229.

Di Luca, C., Ivorra, F., Massa, P. \& Fenoglio, R. 2015 Iron-alumina synergy in the heterogeneous Fenton-type peroxidation of phenol solutions. Chemical Engineering Journal 268, 280-289.

Dutta, G., Waghmare, U. V., Baidya, T., Hegde, M. S., Priolkar, K. R. \& Sarode, P. R. 2006 Origin of Enhanced Reducibility/Oxygen Storage Capacity of $\mathrm{Ce}_{1-\mathrm{x}} \mathrm{Ti}_{\mathrm{x}} \mathrm{O}_{2}$ Compared to $\mathrm{CeO}_{2}$ or $\mathrm{TiO}_{2}$. Chemical Materials 18, 3249-3256.

Guo, L., Chen, F., Fan, X., Cai, W. \& Zhang, J. 2010 S-doped $\alpha-\mathrm{Fe}_{2} \mathrm{O}_{3}$ as a highly active heterogeneous Fenton-like catalyst towards the degradation of acid orange 7 and phenol. Applied Catalysis B 96, 162-168.

Hammedi, T., Triki, M., Ksibi, Z., Ghorbel, A. \& Medina, F. 2015a Comparative study of textural, structural and catalytic properties of xerogels and aerogels $\mathrm{CeO}_{2}-\mathrm{TiO}_{2}$ mixed oxides. Journal of Porous Materials 22, 939-948.

Hammedi, T., Triki, M., Ksibi, Z., Ghorbel, A. \& Medina, F. 2015b Catalytic wet hydrogen peroxide oxidation of p-hydroxybenzoic acid over $\mathrm{Fe} / \mathrm{TiO}_{2}$ and $0.5 \mathrm{Ru}-3 \mathrm{Fe} / \mathrm{TiO}_{2}$. Journal of Sol Gel Science and Technology 76, 679-685. 
Hartmann, M., Kullmann, S. \& Keller, H. 2010 Wastewater treatment with heterogeneous Fenton-type catalysts based on porous materials. Journal of Materials Chemistry 20, 9002-9017.

Heckert, E. G., Seal, S. \& Self, W. T. 2008 Fenton-Like Reaction Catalyzed by the Rare Earth Inner Transition Metal Cerium. Environmental Science and Technology 42, 5014-5019.

Hu, P. \& Long, M. 2016 Cobalt-catalyzed sulfate radical-based advanced oxidation: A review on heterogeneous catalysts and applications. Applied Catalysis B 181, 103-117.

Inchaurrondo, N. S., Massa, P., Fenoglio, R., Font, J. \& Haure, P. 2012 Efficient catalytic wet peroxide oxidation of phenol at moderate temperature using a high-load supported copper catalyst. Chemical Engineering Journal 198-199, 426-434.

Ji, P., Wang, L., Chen, F. \& Zhang, J. $2010 \mathrm{Ce}^{3+}$-Centric Organic Pollutant Elimination by $\mathrm{CeO}_{2}$ in the Presence of $\mathrm{H}_{2} \mathrm{O}_{2}$. ChemCatChem 2, 1552-1554.

Kurian, M. \& Nair, D. S. 2015 Heterogeneous Fenton behavior of nano nickel zinc ferrite catalysts in the degradation of 4-chlorophenol from water under neutral conditions. Journal of Water Process Engineering 8, e37-e49.

Kwnon, B. G., Lee, D. S., Kang, N. \& Yoon, J. 1999 Characteristics of p-chlorophenol oxidation by Fenton's reagent. Water Research 33, 2110-2118.

Liu, Y., Jin, W., Zhao, Y., Zhang, G. \& Zhang, W. 2017 Enhanced catalytic degradation of methylene blue by $\alpha-\mathrm{Fe}_{2} \mathrm{O}_{3}$ /graphene oxide via heterogeneous photo-Fenton reactions. Applied Catalysis B 206, 642-652.

Lopez, T., Rojas, F., Katz, R., Galindo, F., Balankin, A. \& Buljan, A. 2004 Porosity, structural and fractal study of sol-gel $\mathrm{TiO}_{2}-\mathrm{CeO}_{2}$ mixed oxides. Journal of Solid State Chemistry 177, 1873-1885. 
1 Mamontov, E., Egami, T., Brezny, R., Koranne, M. \& Tyagi, S. 2000 Lattice Defects and

Oxygen Storage Capacity of Nanocrystalline Ceria and Ceria-Zirconia. Journal of Physical Chemistry B 104, 11110-11116.

Nasralla, N., Yeganeh, M., Astuti, Y., Piticharoenphun, S., Shahtahmasebi, N., Kompany, A., Karimipour, M., Mendis, B. G., Poolton, N. R. J. \& Šiller, L. 2013 Structural and spectroscopic study of Fe-doped $\mathrm{TiO}_{2}$ nanoparticles prepared by sol-gel method. Scientia Iranica F 20, 1018-1022.

Munoz, M., Pedro, Z. M., Casas, J. A., Rodriguez, J. J. 2015 Preparation of magnetite-based catalysts and their application in heterogeneous Fenton oxidation-A review. Applied Catalysis B 176-177, 249-265.

Pouran, S. R., Abdul Raman, A. Z. \& Wan Daud, W. M. A. 2014 Review on the application of modified iron oxides as heterogeneous catalysts in Fenton reactions. Journal of Cleaner Production 64, 24-35.

Rivas, F. J., Beltrán, F. J., Frades, J. \& Buxeda, P. 2001 Oxidation of p-hydroxybenzoic acid by Fenton's reagent. Water Research 35, 387-396.

Shoko, E., Smith, M. F. \& McKenzie, R. H. 2009 Mixed valency in cerium oxide crystallographic phases: Valence of different cerium sites by the bond valence method. Physical Review B 79, 134108-134120.

Shukla, P., Wang, S., Sun, H., Ang, H. M. \& Tadé, M. 2010 Adsorption and heterogeneous advanced oxidation of phenolic contaminants using Fe loaded mesoporous SBA-15 and $\mathrm{H}_{2} \mathrm{O}_{2}$. Chemical Engineering Journal 164, 255-260.

Sreeja, PH., \& Sosamony, KJ. 2016 A Comparative study of homogeneous and heterogeneous photo-Fenton process for textile wastewater treatment. Procedia Technol 24, 217- 223.

Wang, Y., Shen, X. \& Chen, F. 2014 Improving the catalytic activity of $\mathrm{CeO}_{2} / \mathrm{H}_{2} \mathrm{O}_{2}$ system by sulfation pretreatment of $\mathrm{CeO}_{2}$. Journal of Molecular Catalysis A 381, 38-45. 
1 Wang, Y., Zhao, H. \& Zhao, G. 2015 Iron-copper bimetallic nanoparticles embedded within ordered mesoporous carbon as effective and stable heterogeneous Fenton catalyst for the degradation of organic contaminants, Applied Catalysis B 164, 396-406.

Wei, X., Wu, H. \& Sun, F. 2017 Magnetite/Fe-Al-montmorillonite as a Fenton catalyst with efficient degradation of phenol. Journal of Colloid and Interface Science 504, 611-619.

\section{Figures captions}

Figure 1 XRD patterns of A: (a) $\mathrm{CeTi}(1 / 4)$, (b) $\mathrm{CeTi}(1 / 5)$, (c) $\mathrm{CeTi}(1 / 6)$, (d) $\mathrm{TiO}_{2}$, and (e) $\mathrm{CeO}_{2}$ and $\mathrm{B}$ : (a) $\mathrm{CeTi}(1 / 5)$, (b) $3 \mathrm{Fe} / \mathrm{CeTi}-\mathrm{C}$, (c) $3 \mathrm{Fe} / \mathrm{CeTi}-\mathrm{R}$, (d) $\mathrm{TiO}_{2}$, (e) $3 \mathrm{Fe} / \mathrm{Ti}-\mathrm{C}$, (f) $\mathrm{TiO}_{2}$, and $(\mathrm{g}) \mathrm{CeO}_{2}$.

Figure $2 \mathrm{H}_{2}$-TPR profiles of (a) $\mathrm{CeO}_{2}$, (b) $\mathrm{CeTi}(1 / 5)$, (c) $3 \mathrm{Fe} / \mathrm{CeTi}-\mathrm{C}$, (d) $3 \mathrm{Fe} / \mathrm{CeTi}-\mathrm{R}$, and (e) $3 \mathrm{Fe} / \mathrm{Ti}-\mathrm{C}$.

Figure 3 TEM images of (a) $\mathrm{TiO}_{2}$; (b) $\mathrm{CeTi}(1 / 5)$, (c) $3 \mathrm{Fe} / \mathrm{CeTi}-\mathrm{C}$, and (d) $3 \mathrm{Fe} / \mathrm{CeTi}-\mathrm{R}$.

Figure 4 XPS spectra of 3Fe/CeTi-C: (a) Fe2p, (b) Ce3d, (c) Ti2p, and (d) O1s.

Figure 5 Evolution of the concentrations of $\mathrm{p}-\mathrm{HBZ}$ and intermediates over supported $\mathrm{Fe}$ catalysts. $\mathrm{H}_{2} \mathrm{O}_{2} / p-\mathrm{HBZ}$ molar ratio $=14 / 1, \mathrm{pH} 03.2, m_{\text {catalyst }}=30 \mathrm{mg}, \mathrm{T}=60{ }^{\circ} \mathrm{C}$.

Figure 6 Effect of $\mathrm{pH}$ on the oxidation of $\mathrm{p}-\mathrm{HBZ}$ over $3 \mathrm{Fe} / \mathrm{CeTi}-\mathrm{C} . \mathrm{H}_{2} \mathrm{O}_{2} / \mathrm{p}-\mathrm{HBZ}$ molar ratio $=14 / 1, m_{\text {catalyst }}=30 \mathrm{mg}, \mathrm{T}=60^{\circ} \mathrm{C}$.

Figure 7 Effect of $\mathrm{H}_{2} \mathrm{O}_{2} / \mathrm{p}-\mathrm{HBZ}$ molar ratio on the oxidation of $\mathrm{p}-\mathrm{HBZ}$ over $3 \mathrm{Fe} / \mathrm{CeTi}-\mathrm{C}$. $m_{\text {catalyst }}=30 \mathrm{mg}, \mathrm{T}=60^{\circ} \mathrm{C}, \mathrm{pH} 03.2$.

Figure 8 Plots of $\ln \left(\mathrm{C}_{0} / \mathrm{C}_{\mathrm{t}}\right)$ versus time for the oxidation of $\mathrm{p}-\mathrm{HBZ}$ over $3 \mathrm{Fe} / \mathrm{CeTi}-\mathrm{C}$ at different temperatures. 
2 Table 1 Textural and structural properties of the prepared materials.

3 Table 2 Initial reaction rates and catalytic properties of supported $\mathrm{Fe}$ catalysts for the 4 oxidation of $\mathrm{p}-\mathrm{HBZ}$ at $60{ }^{\circ} \mathrm{C}$.

5 Table 3 Catalytic behavior of $3 \mathrm{Fe} / \mathrm{CeTi}-\mathrm{C}$ at different reaction temperatures. 